\title{
Impact Human Capital Development on Poverty Alleviation and Social Inequality in Riau of Island, Indonesia
}

\author{
Nurmala Mustika Dewi, Rahmayandi Mulda
}

\begin{abstract}
The purpose of this study is to impact of human capital development on poverty alleviation and social inequality is important, given its policy implications especially with respect to the developing countries particularly in Indonesia. The study examines the relationship between some elements of human capital development, poverty alleviation, and social inequality. It investigates the causal relationship between the human capital development explicitly measured on through targeted social assistence and its impact on poverty alleviation and social inequality measured by per capita income over the period of time stated. The study uses Granger causality test through a vector error correction mechanism (VECM), to determine whether the elements of through targeted social assistence of any precedence or effect(s) on per capita income.
\end{abstract}

Keywords : Human Capital Development, Poverty Alleviation, Social Inequality, Social Assistance, Percapita Income.

\section{INTRODUCTION}

The poverty rate in Indonesia has decreased even reaching single digit in 2018, which is 9.82 per cent in March and 9.66 per cent in September 2018. This figure is the lowest poverty rate since 1999 . However, there are still indications of chronic poverty in the lowest income group population, which makes efforts to reduce poverty a priority and is carried out more intensively. On the other hand, developments in national inequality or Gini ratios have also shown improvement in recent years. Indonesia had experienced a relatively fast increase in the Gini ratio in the period 2003 to 2012. This Gini ratio was relatively stagnant in the range of 0.41 in the period 2012-2014, then in 2015 and beyond showed a downward trend to reach 0.389 at the beginning of 2018 and back down to 0.384 in September 2018 .

The reduction in the level of poverty and social inequality is caused by many factors, one of which is the improvement in the level of income of the community. This increase in people's income can be indicated by an increase in household consumption/expenditure. Other factors that influence the improvement of poverty and inequality are among others driven by increases in wages of farm labourers and buildings, labour-intensive infrastructure development, social

Revised Manuscript Received on October15, 2019

* Correspondence Author

Nurmala Mustika Dewi, Program Pascasarjana, Riau Kepulauan University, Batam, Indonesia. Email: nurmalamustikadewi@ gmail.com

Rahmayandi Mulda, Faculty Social Sciences and Political Sciences, Riau Kepualaun University, Batam, Indonesia. Email: muldarahmayandi@gmail.com assistance, and the improvement of income of lower-class government apparatus. If viewed based on the business field, households working in the extractive sector (agriculture and mining) make a major contribution to the change in the ratio of this, because fluctuations in per capita expenditure in the industrial sector and services are relatively small. This is mainly due to fluctuating commodity prices.

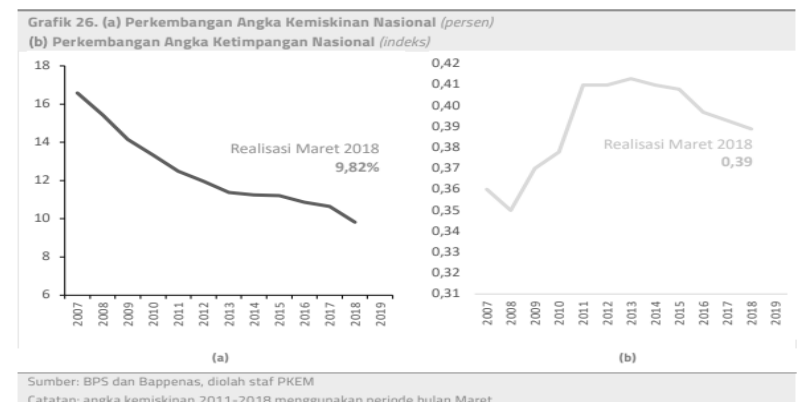

\section{Graph 1. Developments in National Poverty and Ineaquality}

When viewed from the State Budget and Expenditure, the Government as a human capital development to eradicate poverty and social inequality through social assistance must monitor and evaluate programs that are directly related to the welfare of the community so that fiscal policies can be more effective in achieving development goals. This evaluation was carried out by considering challenges and obstacles in reducing poverty in Indonesia. Evaluation of these programs was carried out by using the benefit incidence to see more in the effectiveness of the program, the existence of inclusion and exclusion errors, and the adequacy of assistance by looking at the proportion of assistance to household expenditure (RT). From various programs, this analysis only focuses on the main programs currently available, namely Social Assistance in the form of Prosperous Rice (Rastra) / Non-Cash Food Aid (BPNT), Family Hope Program (PKH), and Smart Indonesia Program (PIP).

The role of human resource development in alleviating poverty and social inequality has become a topical issue for researchers from time to time to find solutions to ineffective policies and programs that have been carried out by the government to reduce and reduce poverty in Indonesia. Therefore, this paper will review some of the existing literature, thereby making relevant contributions to the researchers.

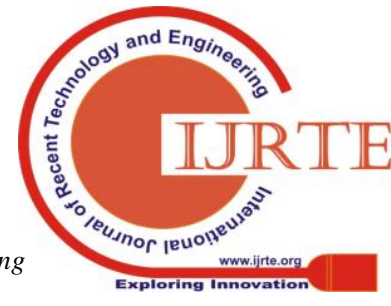




\section{LITERATURE REVIEW}

\section{A. Human Capital}

According to Kayode ${ }^{1}$, human resources comprise a combination of knowledge, abilities, skills, and competencies. Nonetheless, among the factors of production, humans can learn, adapt to changes, innovate and be creative. Besides, human capital formation, as posited by Harbison ${ }^{2}$ is regarded as "the deliberate and continuous process of acquiring requisite knowledge, skills, and experiences that are applied to produce economic value for driving sustainable national development."

Human capital accumulation can be derived from investing in individuals or group of individuals via education, training and skill development and social security schemes. However, according to Schultz ${ }^{3}$, it is crucial to develop the skills, expertise, and knowledge of people who are value creators. Schultz further some ways for developing human capital which includes: investment in services that are construed to improve life expectancy and general well-being of the people, training, and development (both on-the-job and off-the-job), and formal education at all levels (including adult education).

The classical theory of human capital: One of the greatest economic writings to date was authored by Adam Smith who is considered to be the leader of the Classical school of economic thought. In his book "An Inquiry into the Nature and Causes of The Wealth of Nations-Book 2; Of the Nature, Accumulation, and Employment of Stock" $^{4}$ he wrote "Fourthly, of the acquired and useful abilities of all the inhabitants or members of the society. The improved dexterity of a workman may be considered in the same light as a machine or instrument of trade which facilitates and abridges labour, and which, though it costs a certain expense, repays that expense with a profit."

\section{B. Poverty Alleviation}

Poverty according to the World Bank ${ }^{5}$ is construed to be a deprivation in the personal well-being of individuals or a group of people. It comprises people with the inability to attain the necessary materials for living and survival resulting from their low incomes. Poverty is also stated to include elements of poor health conditions, low rate of literacy, inaccessibility to drinkable water and safe environment, lack of adequate security and lack of access to lifechanging opportunities $^{6}$.

Suich and Mace "'that ecosystem services support well-being, and perhaps prevent people becoming poorer, but provide little evidence of their contribution to poverty alleviation, let alone poverty elimination. A considerable gap remains in understanding the links between ecosystem services and poverty, how change occurs, and how pathways out of poverty may be achieved based on the sustainable utilisation of ecosystem services." Causes of poverty: According to Imam7, Ogwunike, Fafowora ${ }^{8}$, Mc Caston and Rewald $^{9}$, Ijaiya ${ }^{10}$, the following are the fundamental causes of poverty:

Inadequate access to employment opportunities for the poor and inadequate access to the means of fostering rural development in poor regions. This is caused mainly by the stunted growth of economic activities or growth with labour savings devices. Developing countries are widely known for their act of consuming more than they can produce if at all they have the capacity and ability to produce.

It is also a significant problem in the rural areas as there are few or no access to markets for the goods and services that the poor can sell. This is as a result of the geographical location of such areas which because of their distances, bad road network and communication problems have left them in the mud of poverty since they are unable to distribute their products for sales hence causing them into unavoidable hardship just to earn a living.

\section{METHODS}

The empirical relationship between human capital development and poverty alleviation has been investigated through some approaches for a long time. Some of the notable methodological techniques that are used in estimating such relationships are Vector Error Correction Mechanism (VECM) based causality test, Johansen cointegration test, etc. Studies like Sikander amongst others used Augmented DickeyFuller (ADF), causality and Johansen cointegration tests to establish the relationship between the variables of concern. Other techniques used are regression analysis. Since the main focus of this study is to determine the effect of human capital development on poverty alleviation, the following economic techniques shall be used which includes cointegration tests (Johansen cointegration approach) and unit root tests (Augumented Dickey-Fuller test and Philips Perron test), Granger causality test and the vector error correction model.

The research employs the use of two models which is an attempt to capture the human capital development using program social assistance and welfare. The first model is theoretically stated as Per Capita Income (PCI) which is a proxy for poverty alleviation and social inequality which depends on government Expenditure on Program Social Assistance (GEPS), Life Expectancy (LE) and walfare (WLF), as a proxy for Social assistance. Therefore;

$\mathrm{PCI}=f(\mathrm{GEPS}, \mathrm{LE}, \mathrm{WLF})$

The second model is stated as Per Capita Income (PCI) which is a proxy for poverty alleviation and social inequality which depends on Government Expenditure on Walfare (GEW), Gross Enrolment Rate (GER) and Fortune Rate (FOR), as a proxy for walfare. Therefore;

$\mathrm{PCI}=f(\mathrm{GEW}, \mathrm{GER}, \mathrm{FOR})$

The multiple linear regression can be stated as; $\mathrm{PCI}=\beta 0+\beta 1 \mathrm{GEPS}+\beta 2 \mathrm{LE}+\beta 3 \mathrm{WLF}+\mu$

$\mathrm{PCI}=\alpha 0+\alpha 1 \mathrm{GEW}+\alpha 2 \mathrm{GER}+\alpha 3 \mathrm{FOR}+\mu$

Where;

$f=$ Functional Relationship; $\beta 0, \beta 1, \beta 2, \beta 3, \alpha 0, \alpha 1, \alpha 2$, and $\alpha 3=$ Coefficient Parameters; GEPS $=$ Government Expenditure on Program Social Assistance; LE=Life Expectancy; $\mathrm{WLF}=$ Walfare; GEW=Government Expenditure on Walfare; GER=Gross Enrolment Rate; FOR=Fortune Rate; PCI=Per Capita Income; $\mu=$ error term. 


\section{DATA ANALYSIS}

\section{Unit Root Test}

The Table 1 below shows the unit root of each variable at level and first difference. Two methods of test of stationarity are used that is, the Augmented Dickey-Fuller test and Phillip-Perron test. Both

\begin{tabular}{|c|c|c|c|c|c|c|c|c|c|}
\hline \multirow[b]{2}{*}{ Variables } & \multirow{2}{*}{ Level } & \multicolumn{2}{|c|}{$\mathrm{ADF}$} & \multirow{2}{*}{$\begin{array}{l}5 \% \text { Critical } \\
\text { Value }\end{array}$} & \multirow[b]{2}{*}{ Variables } & \multirow[b]{2}{*}{ Level } & \multirow{2}{*}{$\begin{array}{c}\text { PP } \\
5 \% \text { Critical } \\
\text { Value } \\
\end{array}$} & \multirow{2}{*}{$\begin{array}{c}\text { First } \\
\text { Difference }\end{array}$} & \multirow{2}{*}{$\begin{array}{l}5 \% \text { Critical } \\
\text { Value }\end{array}$} \\
\hline & & $\begin{array}{l}5 \% \text { Critical } \\
\text { Value }\end{array}$ & $\begin{array}{c}\text { First } \\
\text { Difference } \\
\end{array}$ & & & & & & \\
\hline \multirow{2}{*}{ LFOR } & -1.6 & -2.86 & -3.2 & -2.86 & \multirow{2}{*}{ LFOR } & 1.58 & -2.86 & -3.56 & -2.86 \\
\hline & -0.58 & -2.86 & 0 & -2.86 & & -0.5 & -2.86 & 0 & -2.86 \\
\hline \multirow{2}{*}{ LGER } & -2.96 & -2.86 & -4.6 & -2.86 & \multirow{2}{*}{ LGER } & -2.08 & -2.86 & -5.08 & -2.86 \\
\hline & -0.04 & -2.86 & 0 & -2.86 & & -0.24 & -2.86 & 0 & -2.86 \\
\hline \multirow{2}{*}{ LGEPS } & -2.24 & -2.86 & 7.52 & -2.86 & \multirow{2}{*}{ LGEPS } & -1.58 & -2.86 & -7.84 & -2.86 \\
\hline & (0.18) & -2.86 & 0 & -2.86 & & -0.46 & -2.86 & 0 & -2.86 \\
\hline \multirow{2}{*}{ LGEW } & -2.36 & -2.86 & -5.6 & -2.86 & \multirow{2}{*}{ LGEW } & -2.4 & -2.86 & -6.36 & -2.86 \\
\hline & 0.16 & -2.86 & 0 & -2.86 & & -0.16 & -2.86 & 0 & -2.86 \\
\hline \multirow{2}{*}{ LLE } & 2.84 & -2.86 & -3.02 & -2.86 & \multirow{2}{*}{ LLE } & 2.42 & -2.86 & -6.8 & -2.86 \\
\hline & -1 & -2.86 & 0 & -2.86 & & -0.98 & -2.86 & 0 & -2.86 \\
\hline \multirow{2}{*}{ LPCI } & -0.05 & -2.86 & $-4,62$ & -2.86 & \multirow{2}{*}{ LPCI } & -0.48 & -2.86 & -4.65 & -2.86 \\
\hline & -0.95 & -2.86 & 0 & -2.86 & & -0.89 & -2.86 & 0 & -2.86 \\
\hline \multirow{2}{*}{ LWLF } & -1.06 & -2.86 & -4.02 & -2.86 & \multirow{2}{*}{ LWLF } & -3.82 & -2.86 & -4.67 & -2.86 \\
\hline & 0.7 & -2.86 & 0 & -2.86 & & -1 & -2.86 & 0 & -2.86 \\
\hline
\end{tabular}

Source: E-views 10 computation by author

The test gives the same result about the calculates of the variables. All variables are found to be non-stationary at levels but stationary at first difference in both the Augmented Dickey-Fuller and Philip-Perron tests. Since all the variables are stationary at first difference, we applied the cointegration and vector autoregressive based modelling techniques which enabled the possible autoregressive relationship in the set of variables.

\begin{tabular}{|l|c|c|c|}
\hline \multicolumn{1}{|c|}{ Null Hyphotesis } & Obs & F-Statistic & Prob. \\
\hline $\begin{array}{l}\text { LGEW does not Granger } \\
\text { Cause LPCI }\end{array}$ & 36 & 0,5338 & 0,5924 \\
\hline $\begin{array}{l}\text { LPCI does not Granger } \\
\text { Cause LGEW }\end{array}$ & 36 & 1,8322 & 0,1794 \\
\hline $\begin{array}{l}\text { LGEPS does not Ganger } \\
\text { Cause LPCI }\end{array}$ & 36 & 7,68436 & 0,0023 \\
\hline $\begin{array}{l}\text { LPCI does not Granger } \\
\text { Cause LGEPS }\end{array}$ & 36 & 1,98042 & 0,1576 \\
\hline $\begin{array}{l}\text { LGER does not Granger } \\
\text { Cause LPCI }\end{array}$ & 36 & 0,13079 & 0,878 \\
\hline $\begin{array}{l}\text { LPCI does not Ganger } \\
\text { Cause LGER }\end{array}$ & 36 & 1,31387 & 0,2854 \\
\hline $\begin{array}{l}\text { LWLF does not Ganger } \\
\text { Cause LPCI }\end{array}$ & 36 & 2,33183 & 0,1164 \\
\hline $\begin{array}{l}\text { LPCI does not Ganger } \\
\text { Cause LWLF }\end{array}$ & 36 & 1,16282 & 0,3278 \\
\hline $\begin{array}{l}\text { LLE does not Ganger } \\
\text { Cause LPCI }\end{array}$ & 36 & 5,997787 & 0,007 \\
\hline $\begin{array}{l}\text { LPCI does not Ganger } \\
\text { Cause LLE }\end{array}$ & 36 & 1,37135 & 0,2709 \\
\hline $\begin{array}{l}\text { LFOR does not Ganger } \\
\text { Cause LPCI }\end{array}$ & 36 & 6,56834 & 0,0047 \\
\hline $\begin{array}{l}\text { LPCI does not Ganger } \\
\text { Cause LFOR }\end{array}$ & 36 & 2,13894 & 0,1373 \\
\hline Source: E-VieW 10 Compun & & \\
\hline
\end{tabular}

Source: E-Views 10 Computation by Author

\section{FINDINGS AND DISCUSSION}

From various programs, this analysis only focuses on the main programs currently available, namely Social Assistance in the form of Prosperous Rice (Rastra) / Non-Cash Food Aid (BPNT), Family Hope Program (PKH), and Smart Indonesia Program (PIP).

\section{Benefit Incident of Rastra}

The benefit incidence calculation shows that Rastra is progressive because it is enjoyed more by poorer groups of household (RT). However, this calculation still shows inclusion and exclusion errors. Inclusion errors were seen because there were still RTs in decile groups 4-10 who received Prosperous Rice (Rastra) Subsidies. The household (RT) group of the richest 20 per cent, which should not receive subsidies and social assistance, still enjoys 7.7 per cent of the total Prosperous Rice (Rastra) subsidy. Meanwhile, indications of exclusion errors were shown by the proportion of the poorest 25 percent of the household (RT) who had not all received Prosperous Rice (Rastra).

The change in the mechanism for distributing food aid is expected to increase the accuracy of the target, the accuracy of the amount, and the timeliness. However, several things that need to be done for the implementation of BPNT are the need for socialization and education to the public related to 
the use of financial services (financial inclusive) and increasing the number of the supply side in the form of e-waroeng. This is interesting to explore further using Susenas data in 2018 to see changes from the Prosperous Rice (Rastra) subsidy to social assistance Prosperous Rice (Rastra) / BPNT.

\section{Benefit Incidence of PKH}

A benefit incidence analysis shows that Family Hope Program $(\mathrm{PKH})$ is progressive because poorer RTs receive more assistance than those with higher economic classes. Of the total Family Hope Program (PKH) assistance provided, the household (RT) group had the poorest 40 percent or benefited by 67.5 percent. The rest is enjoyed by household (RT) groups in higher economic classes who should not receive social assistance. This indicates there is still an error in inclusion in Family Hope Program (PKH). The household (RT) group of the richest 20 percent also still enjoys Family Hope Program $(\mathrm{PKH})$ even though in very small amounts (3.1 percent of the total Family Hope Program (PKH) assistance).

Various efforts have been made to improve the effectiveness of the program to increase the impact of the program on reducing poverty and inequality. Continuous improvement of the database is carried out to improve the accuracy of data targeting through the improvement of the independent update mechanism carried out by involving the Regional Government. Also, for 2019 Family Hope Program (PKH) assistance is again using a non-flat scheme by the conditionality of beneficiary families and the benefits for each component of education and health are increased to double. Effectiveness can also be improved by synergizing Family Hope Program (PKH) with community empowerment programs to increase independence (Joint Business / KUBE Group, People's Business Credit / KUR, Ultra-micro Financing / UMi) and strengthening employment (job training).

\section{Benefit Incidence of Smart Indonesia Program (PIP)}

Besides PKH, Smart Indonesia Program (PIP) is also one of the most effective social assistance programs in reducing poverty and inequality. The benefits provided through PIP are progressive because they are enjoyed more by the poorer population. Of the total Smart Indonesia Program (PIP) assistance provided, the poorest 40 percent of the household (RT) group received about half of the total Smart Indonesia Program (PIP) assistance, 58.5 percent. Meanwhile, the richest 20 percent of the household (RT) group still enjoyed 5.9 percent of the total Smart Indonesia Program (PIP) assistance. As with Family Hope Program (PKH), this also indicates an inclusion error in targeting Smart Indonesia Program (PIP) recipients.

Based on best practices from other countries, the optimal portion of subsidies and social assistance to poor household income/expenditure is around 30 percent. The portion of Indonesia's subsidies and social assistance in 2017 was around 29 percent of the expenditure of poor households, which means it is still quite ideal. However, along with the economic dynamics and transformation of social assistance policies, the portion of social assistance distribution to household expenditure needs to be continuously optimized to keep the number, on time, target more precise. If the social assistance provided is too large, it is feared that it can make poor and vulnerable households dependent and counterproductive. Conversely, if it is too low it can also have an impact on efforts to reduce poverty and inequality.

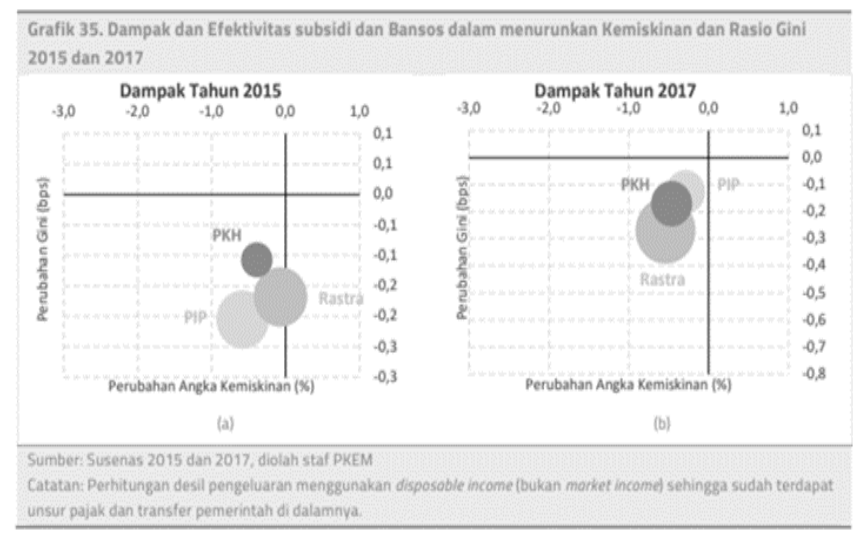

Graph 2. Impact and Effective Program in Reducing Poverty and Inequality

From various programs, can be concluded that Family Hope Program (PKH) is still the most effective program in reducing poverty and inequality. In other words, for every Family Hope Program (PKH) rupiah (per Rp. 100 trillion) it gives higher effectiveness in reducing poverty and the Gini Ratio. The effectiveness of Family Hope Program (PKH) can reduce poverty by 6.9 percentage points and the Gini ratio by 2.5 basis points. Therefore, with the same budget as other programs, the impact of Family Hope Program (PKH) will be greater than other types of social assistance. Graph 36 shows that Rastra is the least effective in reducing poverty and inequality. This has become the government's concern to make improvements in terms of distribution, namely Rastra Aid will fully transform into BPNT in 2019. In the future, social assistance will continue to be able to keep the consumption of poor and vulnerable people out of poverty and reduce inequality while avoiding dependency and counterproductive to economic development.

\section{CONCLUSION}

This paper it can be concluded that Family Hope Program (PKH) is still the most effective program in reducing poverty and inequality. In other words, for every Family Hope Program (PKH) rupiah (per Rp. 100 trillion) it gives higher effectiveness in reducing poverty and the Gini Ratio.

\section{Graph 3. Effectivities Program Social Assistance on}

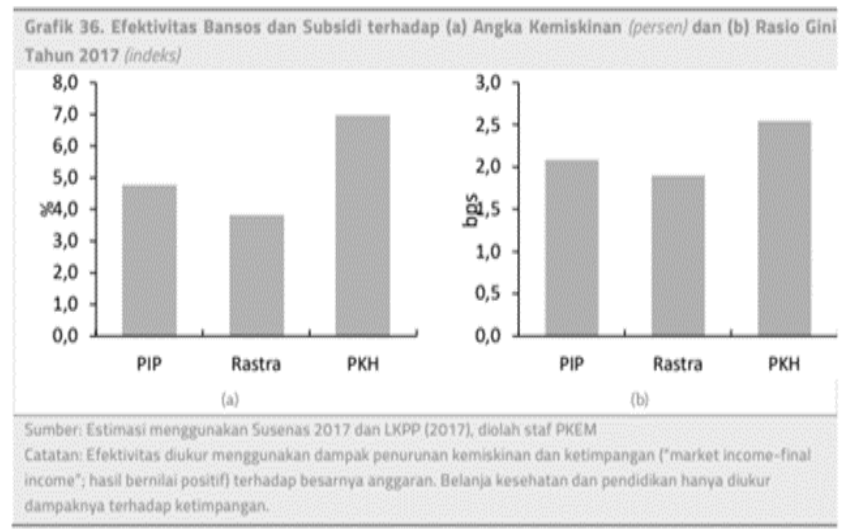

poverty and inequality 
The effectiveness of Family Hope Program (PKH) can reduce poverty by 6.9 percentage points and the Gini ratio by 2.5 basis points (Graph 3 ). Therefore, with the same budget as other programs, the impact of Family Hope Program (PKH) will be greater than other types of social assistance. Graph 3 shows that Prosperous Rice (Rastra) is the least effective in reducing poverty and inequality. This has become the government's concern to make improvements in terms of distribution, namely Prosperous Rice (Rastra) Aid will fully transform into BPNT in 2019. In the future, social assistance will continue to be able to keep the consumption of poor and vulnerable people out of poverty and reduce inequality while avoiding dependency and counterproductive to economic development.

\section{REFERENCES}

1. Kayode A (2012) Human capital development and poverty alleviation in Nigeria: A symbiotic overview. Journal of Public Administration and Governance, pp: 1-15.

2. Harbison FH (1973) Human resources as the wealth of nations. Oxford University Press, New York, USA.

3. Schultz TW (1961) Investment in Human Capital. The American Economic Review 1: 1-17.

4. Smith A (1776). The wealth of nations. Modern Library, New York: USA.

5. World Bank Report (2013) Human Capital Index.

6. Melio MS (2015). The Challenges of Poverty Measurement in the Arab Region. International Association for Income and Wealth Conference.

7. Suich, H., Howe, C., \& Mace, G. (2015). Ecosystem services and poverty alleviation: A review of the empirical links. Ecosystem Services, 12, 137-147. https://doi.org/10.1016/j.ecoser.2015/02/005.

8. Imam H (1998). Why poverty defines solution. Business Times Monday, p: 5 .

9. Fafowora O (2002) Global prosperity and poverty. The Comet, p: 34.

10. McCaston MK, Rewald M (2005) Conceptual overview of underlying causes of poverty, pp: 1-27.

11. Ijaiya GT (2007) Poverty alleviation programmes. In: Saliu H, Amali E, Olawepo R (eds.) Nigeria's reform programme: Issues and Challenges. Concept Publishing, Lagos.

12. Ministry of Finance, Fiscal Policy, Edisi 1, 2019. Effort to reduce poverty and inequality through targeted social assistance. ISSN 2527-3140.

13. Central Bureau of Statistics, 2019

\section{AUTHORS PROFILE}

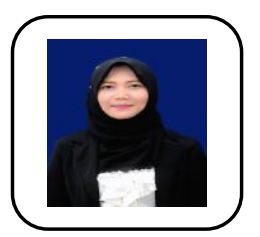

Nurmala Mustika Dewi is master student at the Pascasarjana Riau Kepulauan University

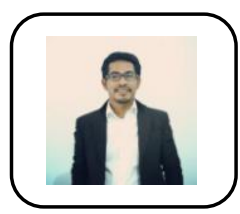

Rahmayandi Mulda is dean Faculy social science and political science Riau Kepulauan University. 